\title{
New Biocomposite Electrospun Fiber/Alginate Hydrogel for Probiotic Bacteria Immobilization
}

\author{
Adam Grzywaczyk ${ }^{1}$, Agata Zdarta ${ }^{1}{ }^{\circledR}$, Katarzyna Jankowska ${ }^{1}$, Andrzej Biadasz ${ }^{2}$, Jakub Zdarta ${ }^{1}(\mathbb{0}$, \\ Teofil Jesionowski ${ }^{1}$ (D), Ewa Kaczorek ${ }^{1}$ (D) and Wojciech Smułek 1,*(D) \\ 1 Institute of Chemical Technology and Engineering, Faculty of Chemical Technology, Poznan University \\ of Technology, Berdychowo 4, 60-965 Poznan, Poland; adam.grzywaczyk@doctorate.put.poznan.pl (A.G.); \\ agata.zdarta@put.poznan.pl (A.Z.); katarzyna.jankowska@doctorate.put.poznan.pl (K.J.); \\ jakub.zdarta@put.poznan.pl (J.Z.); teofil.jesionowski@put.poznan.pl (T.J.); \\ ewa.kaczorek@put.poznan.pl (E.K.) \\ 2 Institute of Physics, Faculty of Materials Engineering and Technical Physics, Poznan University of Technology, \\ Piotrowo 3, 60-965 Poznan, Poland; andrzej.biadasz@put.poznan.pl \\ * Correspondence: wojciech.smulek@put.poznan.pl
}

Citation: Grzywaczyk, A.; Zdarta,

A.; Jankowska, K.; Biadasz, A.;

Zdarta, J.; Jesionowski, T.; Kaczorek,

E.; Smułek, W. New Biocomposite

Electrospun Fiber/Alginate Hydrogel for Probiotic Bacteria Immobilization.

Materials 2021, 14, 3861. https://

doi.org/10.3390/ma14143861

Academic Editor: Maurice N. Collins

Received: 7 June 2021

Accepted: 8 July 2021

Published: 10 July 2021

Publisher's Note: MDPI stays neutral with regard to jurisdictional claims in published maps and institutional affiliations.

Copyright: (c) 2021 by the authors. Licensee MDPI, Basel, Switzerland. This article is an open access article distributed under the terms and conditions of the Creative Commons Attribution (CC BY) license (https:// creativecommons.org/licenses/by/ $4.0 /)$.

\begin{abstract}
Biotechnological use of probiotic microorganisms involves providing them with appropriate conditions for growth, but also protection against environmental changes caused by an exchange of the medium, isolation of metabolites, etc. Therefore, the research on effective immobilization of probiotic microorganisms should be focused in this direction. The present study aimed to evaluate the effectiveness of an innovative hybrid immobilization system based on electrospun nanofibers and alginate hydrogel. The analyses carried out included the study of properties of the initial components, the evaluation of the degree and durability of cell immobilization in the final material, and their survival under stress conditions. Effective binding of microorganisms to the hydrogel and nanofibers was confirmed, and the collected results proved that the proposed biocomposite is an efficient method of cell protection. In addition, it was shown that immobilization on electrospun nanofibers leads to the preservation of the highest cell activity and the least cell growth restriction as compared to free or lyophilized cells only. The completed research opens new perspectives for the effective immobilization of microorganisms of significant economic importance.
\end{abstract}

Keywords: biocomposite; contact angle; electrospun nanofibers; immobilization; Lactobacillus; alginate hydrogel

\section{Introduction}

To maintain optimal microorganism cultivation, growth media parameters such as $\mathrm{pH}$, temperature, oxygen level, and nutrition agents must be ensured, depending on the species of microbe (Thomas, 2015 [1]). This causes the use of many different specific and non-specific growth media, such as general-purpose nutrient agar (Smułek et al., 2020 [2]) and enrichment broth (Rahman et al., 2020 [3]), specific for certain fungi Sabouraud's agar (Cultrera et al., 2021 [4]), and Middlebrook and Löwenstein-Jensen media used for Mycobacterium spp. culture (Schön et al., 2020 [5]; Xie et al., 2021 [6]) (Mikolajczyk et al., 2016 [7]).

No matter what type of growth media is required, it is crucial is to maintain sterility when working with microorganisms, and prevent microbes from hazardous environmental conditions such as temperature fluctuation, UV radiation, $\mathrm{pH}$ changes, organic solvents, and salts. One possible way to do this is the immobilization of microorganisms-chemically bonding or adsorbing microorganisms onto the surface of the carrier, and entrapment in a form of capsule or gel (Drauz and Waldmann, 1995 [8]). Requirements for the appropriate carrier, such as non-toxicity, optimal mechanical properties, chemical resistance, and cost-effectiveness make the entrapment in calcium or sodium alginate hydrogels the 
most-used technique for cell immobilization (Zhu, 2007 [9]). There are two main types of this process: gel entrapment and encapsulation. Gel entrapment differs from encapsulation in the form of beads. During the gel entrapment, cells are immobilized in a gel matrix, whereas the encapsulation process involves the preparation of porous barrier and entrapment of microorganism in liquid core of such bead (Willaert and Baron, 1996 [10]). Probiotics are the group of microorganism which are most commonly stabilized by the process of encapsulation since their survival in harsh conditions is crucial to trigger the beneficial effect of those microorganisms in human body (Tripathi and Giri, 2014 [11]). Moreover, capsuled microbes have been used in the medical application (Rocha et al., 2021 [12]), the food industry (Penhasi, Reuveni and Baluashvili, 2021 [13]), delivery systems (Cook et al., 2012 [14]), or even in larval rearing system (Ghoname et al., 2020 [15]).

When presenting the process of microbial immobilization, the adsorption process on nanofibers should be mentioned. Nanofibers are one-dimensional structures whose crosssectional diameter is in the nanometric range (from 1 to $100 \mathrm{~nm}$ ). Due to their structure and morphology, there can be distinguished porous, ribbon, branched, or hollow nanofibers, and each of them is created under specific conditions of their production process (Stanishevsky, Wetuski, and Yockell-Lelièvre, 2016 [16]; Li et al., 2017 [17]; Ali, Ain, and HuanHe, 2020 [18]). There are several approaches of nanofibers production such as phase separation, consisting of joint gelation of the polymer and solvent (Ma and Zhang, 1999 [19]). Another technique is molecular self-assembly, which combines individual molecules based on the action of intermolecular forces (Xu, Samways, and Dong, 2017 [20]). During template synthesis polymer is pressed into a special corundum template, which allows obtainment of nanofibers of a defined shape (Wang et al., 2010 [21]). The technology, which has been intensively developed in recent years, known as electrospinning, deserves special attention. This method uses an electrostatic field to obtain fibers with a diameter of a few nanometers. Compared to other methods, electrospinning is cheaper and has a wide range of materials from which nanostructures can be spun. Nanofibers prepared by the electrospinning method have been widely used in many different applications, such as tissue engineering, cosmetics industry, filtration processes, and wastewater treatment (Huang et al., 2003 [22]; Bhardwaj and Kundu, 2010 [23]), as well as microbes adsorption process for different usage. For example, Bao et al. used polyethersulfone nanofibers for simultaneous removal of dyes and bacteria (Bao et al., 2021 [24]), and Jayani et al. used bacterial cellulose nanofibers prepared by the electrospinning method as a carrier material for Lactobacillus acidophilus 016 (Jayani et al., 2020 [25]). However, so far no report could be found for the usage of nanofibers-alginate hydrogel layered structure, as support for bacteria immobilization.

In this study, the layered structure of alginate hydrogel beads with immobilized bacteria cells and polystyrene nanofibers was prepared. The alginate hydrogel were prepared with gravitational dropping $2 \%$ sodium alginate solution from syringe into $1 \%$ calcium chloride solution and then sandwiched with two PS mats via electrospinning process. This layer-by-layer immobilization process was used for improving the stability, chemical, and thermal resistance, as well as reduce the leaching of entrapped bacteria. Moreover, the viability of probiotic bacteria was determined, as well as UV resistance.

\section{Materials and Methods}

\subsection{Bacteria Cultivation and Immobilization on Electrospun Material}

In the research the bacteria strain Lactobacillus plantarum (PCM 2675, Polish Collection of Microorganisms, Wrocław, Poland), which is typically representative of probiotic bacteria. It has been extensively characterized in the literature and has been used in biotechnology. Hence, finding possibilities for its effective immobilization and protection will be very important for producers and also, indirectly, for consumers. The first step in the preparation of the bacterial culture was the establishment of the inoculum of the strain under study. For this purpose, the biomass from Petri dish was transferred from the solid medium to $45 \mathrm{~mL}$ of MRS broth (BTL Poland, Łódź, Poland) using a microbiological loop and incubated for $24 \mathrm{~h}$ at $30^{\circ} \mathrm{C}$ with shaking (120 rpm). Then, all the bacterial inoculum and 
$1.5 \mathrm{~mL}$ of Tween 80 were added to the 1.51 sterile MRS broth previously prepared in the bioreactor. The bioreactor (Biostat B plus, Sartorius, Germany) operating parameters, maintained throughout the culture, were set as follows: $25^{\circ} \mathrm{C}$, stirring using a Rushton turbine type stirrer $150 \mathrm{rpm}$, culture running time 6 days. Afterward, the bacterial culture was transferred to bottles and centrifuged $\left(20 \mathrm{~min}, 4{ }^{\circ} \mathrm{C}, 4500 \mathrm{rpm}\right)$. The biomass was resuspended in $100 \mathrm{~mL}$ of PBS buffer to the optical density $\mathrm{OD}_{600}$ around 2.0, and used for the immobilization procedure. Freeze-dried bacteria and sodium alginate $(3 \%)$ immobilized bacteria were used as a comparison in the experiments. For freeze-drying, $2 \mathrm{~mL}$ of bacterial suspension was placed in a lyophilizer (Alpha 1-2 LD plus, Christ, Germany) for $96 \mathrm{~h}$, $-30{ }^{\circ} \mathrm{C}, 0.36 \mathrm{mbar}$. For bacteria immobilization in sodium alginate (SA), $2 \mathrm{~mL}$ of bacterial suspension was mixed with equal volume of $3 \% \mathrm{SA}$. The beads were formed by dropping the mixture to $200 \mathrm{mM} \mathrm{CaCl}_{2}$ solution.

\subsection{Production of Electrospun Fibers with Encapsulated Bacteria}

Polystyrene (PS, average molecular weight $192,000 \mathrm{~g} \mathrm{~mol}^{-1}$, Sigma-Aldrich, Warsaw, Poland) was dissolved in $\mathrm{N}, \mathrm{N}$-dimethylformamide (DMF, Sigma-Aldrich, Warsaw, Poland) to obtain a $32 \%(w / v)$ solution and next was mixed for $24 \mathrm{~h}$. After that $500 \mu \mathrm{L}$ of Pluronic ${ }^{\circledR \circledR}$ P-123 (Sigma-Aldrich, Warsaw, Poland) was added to increase the hydrophilicity of PS electrospun fibers and mixed for another $2 \mathrm{~h}$. At the same time, sodium alginate was dissolved in water $(24 \mathrm{~h})$ to obtain a $3 \%$ of SA solution. Subsequently, $2 \mathrm{~mL}$ of bacteria solution (OD600 $\approx 2.0$ ) was added to the $2 \mathrm{~mL}$ of SA solution thoroughly. The prepared $\mathrm{PS} / \mathrm{DMF}$ and $\mathrm{SA} /$ bacteria solutions were placed separately into syringes with needle sizes of $20 \mathrm{G}$ and $22 \mathrm{G}$, respectively. The production of electrospun fibers from PS layered with bacteria encapsulated into SA was carried out using electrospinning and electrospraying techniques, respectively. Alternately, electrospun polystyrene (PS) fibers and SA/bacteria electrospray were layered to obtain "sandwich-structure" material consists of three layers of PS fibers and two layers of encapsulated bacteria into SA, in three repetitions (Figure 1). Both outer layers of the material were made from polystyrene.

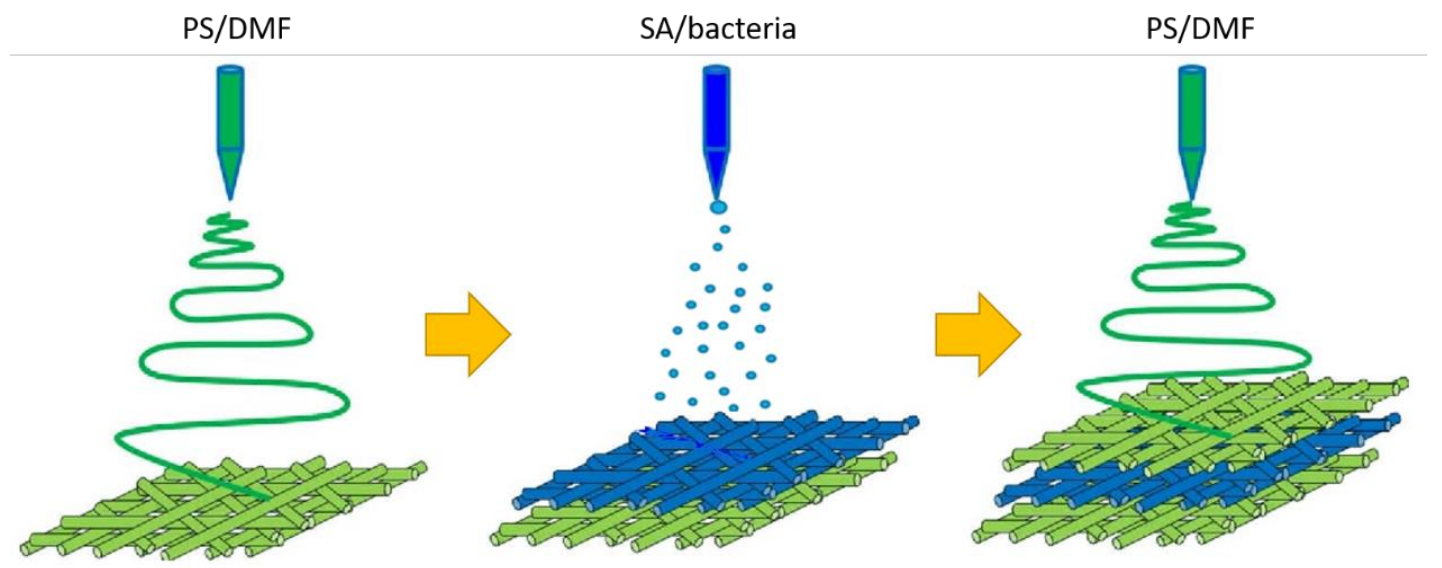

Figure 1. Biocomposite preparation—a workflow scheme.

The electrospinning process of PS was carried out under the following conditions: applied voltage $14 \mathrm{kV}$, feed rate $1 \mathrm{~mL} \mathrm{~h}^{-1}$, the distance between nozzle and collector $15 \mathrm{~cm}$, time of process $2 \mathrm{~min}$. The electrospraying conditions were: applied voltage $25 \mathrm{kV}$, feed rate $0.5 \mathrm{~mL} \mathrm{~h}^{-1}$, the distance between nozzle and collector $15 \mathrm{~cm}$, time of process $10 \mathrm{~min}$. The fibers with bacteria encapsulated were collected on the aluminum foil, which covered the steel collector and dried for $24 \mathrm{~h}$ in a vacuum drier at $23{ }^{\circ} \mathrm{C}$ and $50 \mathrm{mbar}$ (Memmert, Schwabach, Germany). 


\subsection{Material Properties Analysis}

Confocal laser scanning microscopy (CLSM) photographs of the PS electrospun material with or without bacteria were obtained with the LSM710 microscope (Zeiss, Jena, Germany) equipped with the argon laser (laser operated at $453 \mathrm{~nm}$ for reflected light, and $488 \mathrm{~nm}$ for fluorescence mode with the fluorescence observed in the range 510-797 nm).

A scanning electron microscope (SEM) (Hitachi S-3400N, Tokyo, Japan) was applied to observe the surface morphology of the PS/SA/bacteria composite. The average diameter of the PS electrospun fibers was calculated using ImageJ National Institute of Health software (1.53, Bethesda, MD, USA) from 100 points randomly selected from the CLSM images.FT-IR analyses were performed on a Vertex V70 FT-IR spectrometer (Bruker Optik $\mathrm{GmbH}$, Leipzig, Germany) further equipped with a Platinum-ATR-unit (Bruker Optik $\mathrm{GmbH}$, Leipzig, Germany), The material was placed onto the ATR crystal and scanned. To analyze recorded IR spectra the OPUS (7.2, Bruker Optik GmbH, Leipzig, Germany) software was used.

The contact angle was calculated based on measurements made of contact angles of water, LB broth, and milk drops on the surfaces of the materials with the accuracy $\pm 0.01 \mathrm{mN} / \mathrm{m}$ using a Drop Shape Analysis System DSA100E (KRÜSS GmbH, Hamburg, Germany).

\subsection{Evaluation of Bacterial Metabolic Activity}

Immobilized probiotics were subjected to high temperature and UV light tests (UV30A model UV lamp, Esco, Singapore, Singapore). For this purpose, from each material three $3 \mathrm{~cm} \times 3 \mathrm{~cm}$ squares were cut and placed in the incubator at $50^{\circ} \mathrm{C}$ for $24 \mathrm{~h}$ or under UV light ( $\lambda=253 \mathrm{~nm}$; distance to the light $45 \mathrm{~cm}$; exposition time $30 \mathrm{~min})$. Subsequently, materials were placed in the cell culture plate and flooded with $5 \mathrm{~mL}$ of sterile MRS broth. Samples were incubated for $24 \mathrm{~h}, 30^{\circ} \mathrm{C}, 120 \mathrm{rpm}$ and subjected to microbial activity analysis: MTT test and alamarBlue test. The control samples were material squares of the same dimensions without temperature or UV light treatment. The results were compared with the lyophilized bacteria and alginate ( $3 \%$ ) encapsulated bacteria.

In the 96-well microplate, $200 \mu \mathrm{L}$ of each tested bacterial suspension and $20 \mu \mathrm{L}$ of MTT solution ( $5 \mathrm{mg} / \mathrm{mL}$, Sigma-Aldrich, Warsaw, Poland) were mixed to measure metabolic activity. The plate was incubated for $24 \mathrm{~h}$ at $30^{\circ} \mathrm{C}$ until formazan crystals formed. The biomass was then centrifuged and $200 \mu \mathrm{L}$ of isopropanol was added to each well. The plates were left on a shaker with gentle mixing for about $15 \mathrm{~min}$ until the formazan crystals were completely dissolved, then briefly centrifuged, and the clear supernatant was transferred to a clean measuring plate and the absorbance was measured at $600 \mathrm{~nm}$.

Analysis of cell metabolic activity using the alamarBlue reagent (Biorad, Warsaw, Poland) involved applying $200 \mu \mathrm{L}$ of each bacterial culture to a 96-well plate at 3 dilutions with phosphate buffer $(1: 1 ; 1: 2,1: 4)$, then $20 \mu \mathrm{L}$ of alamarBlue reagent was added to each well and incubated at $25^{\circ} \mathrm{C}$ with shaking, taking spectrophotometric measurements every hour at $570 \mathrm{~nm}$ and $600 \mathrm{~nm}$ for $8 \mathrm{~h}$ (Multiskan Sky, Thermo Fisher Scientific, Warsaw, Poland). The results were calculated as a percentage difference in the reduction of the reagent in comparison to control samples, according to Equation (1).

$$
M=\frac{(O 2 * A 1)-(O 1 * A 2)}{(O 2 * P 1)-(O 1 * P 2)} * 100
$$

where:

$O 1=$ molar extinction coefficient of oxidized alamarBlue at $570 \mathrm{~nm}\left(80,586 \mathrm{M}^{-1} \mathrm{~cm}^{-1}\right)$

$\mathrm{O} 2=$ molar extinction coefficient of oxidized alamarBlue at $600 \mathrm{~nm}\left(117,216 \mathrm{M}^{-1} \mathrm{~cm}^{-1}\right)$

$A 1=$ test wells absorbance at $570 \mathrm{~nm}$

$A 2=$ test wells absorbance at $600 \mathrm{~nm}$

$P 1=$ positive growth control well absorbance at $570 \mathrm{~nm}$

$P 2=$ positive growth control well absorbance at $600 \mathrm{~nm}$ 
Two hundred microliters of distilled water supplemented with alamarBlue or MTT reagent were used as blanks. For each system tested, three replicates of the experiment were performed.

\section{Results and Discussion}

\subsection{Characteristic of the Material}

Microscopy

Cross-section morphology of electrospun mats and PS nanofibers with alginate immobilized bacteria (PS/Alg) were characterized based on the CLSM photographs (LSM710, Zeiss, Jena, Germany) in normal and fluorescence mode (Figure 2). Presented results confirm successful immobilization of the probiotic bacteria on the nanofibers. Untreated PS nanofibers display a smooth, uniform surface, with no fluorescence. The fibers morphology became beaded after the immobilization process, comparing it to the pure mat (Figure 2a,c). The beads of oblong shape are distributed along the fibers, with some bigger cluster spots. Moreover, a strong fluorescence of these structures confirms that they are alive probiotic cells. A similar phenomenon has been reported by a previous studies (Mamvura et al., 2011 [26]; Yu et al., 2020 [27]).

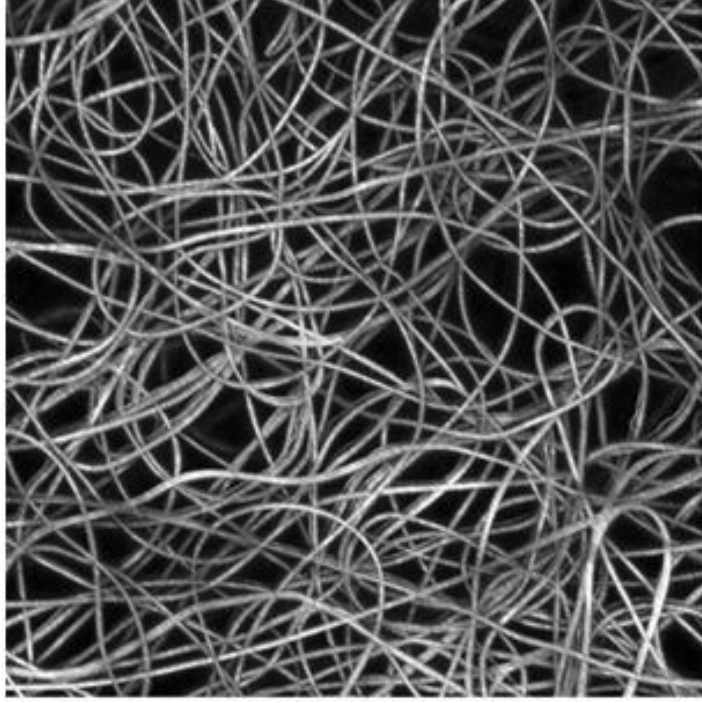

(a)

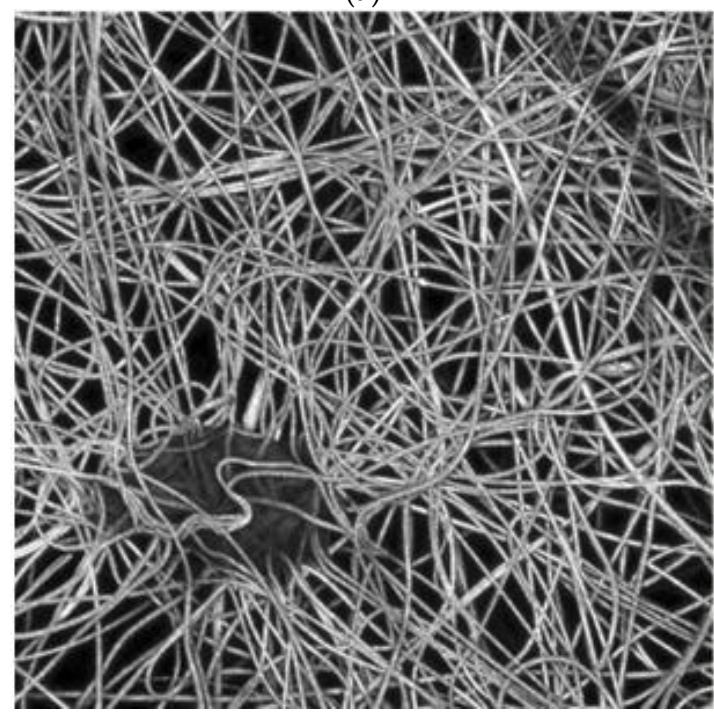

(c)

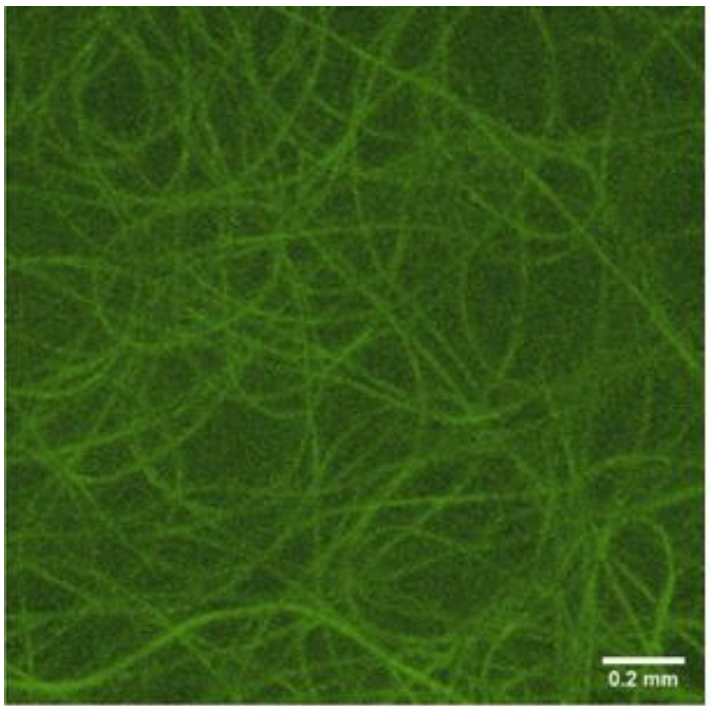

(b)

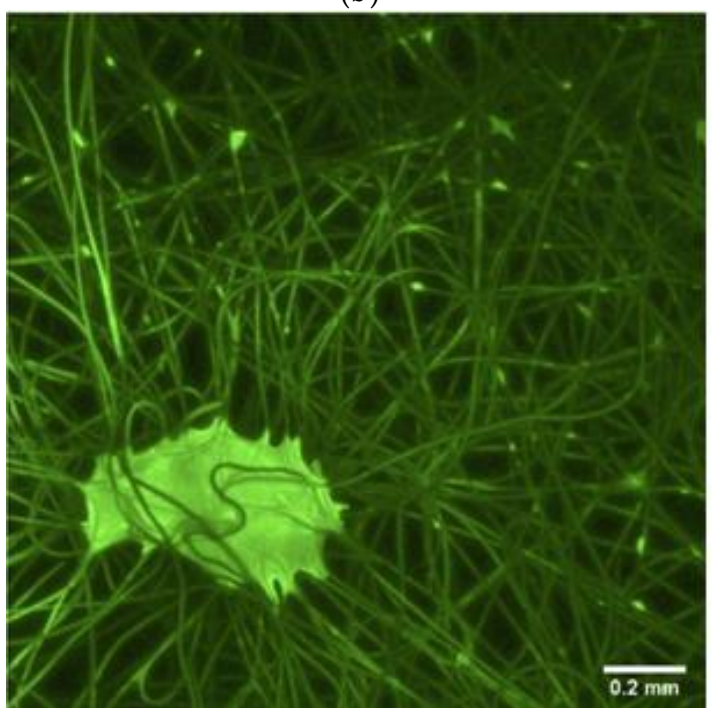

(d)

Figure 2. Cross-section CLSM pictures in normal $(\mathbf{a}, \mathbf{c})$ and fluorescence $(\mathbf{b}, \mathbf{d})$ mode of pure PS material $(\mathbf{a}, \mathbf{b})$ and PS material with alginate immobilized bacteria $(\mathbf{c}, \mathbf{d})$. 
Furthermore, the electrospun PS nanofibers and PS/Alg material were characterized based on the SEM images (S-3400N, Hitachi, Tokyo, Japan) after gold coating (Figure 3). Moreover, the SEM photographs were used for the calculation of the average diameters of electrospun fibers. Presented photos of the top view confirmed that the electrospinning process was successfully used for nanofibers production. Fibers did not possess any beads or entanglements which proves that and process conditions were chosen correctly. Figure $3 b$ shows that PS/Alg material possesses intercalated alginate hydrogel particles (visible in the background, behind PS fibers). Nanofibers' diameter is constant through the whole membrane and equals $\sim 6 \mathrm{~nm}$ for both PS and PS/Alg materials. The same conclusions were drawn by Deng et al., who used electrospun polystyrene nanofibers as a mat for filtering atmospheric air from the heavy metal trace. They used the PS/DMF/THF solution for the production process, with the following electrospinning settings: voltage $20 \mathrm{kV}$, dosing speed (feeding rate) $1 \mathrm{~mL} \mathrm{~h}^{-1}$, and needle-collector distance $20 \mathrm{~cm}$. The diameter of obtained nanofibers was $407.6 \pm 118.7 \mathrm{~nm}$ (Deng et al., 2020 [28]).
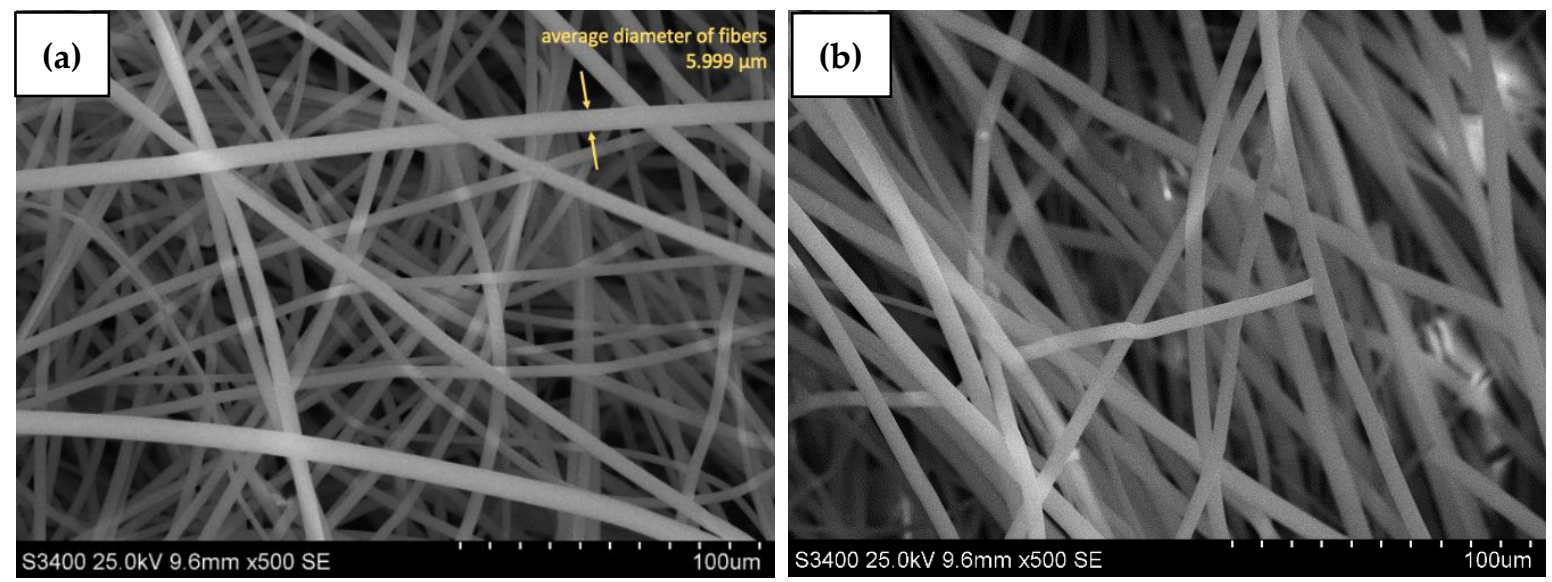

Figure 3. Top-view SEM pictures of PS nanofibers (a) and PS nanofibers with alginate immobilized bacteria (b) with a magnitude of 500 .

To further investigate the tested materials, infrared spectra of the materials were undertaken (Figure 4). The obtained spectra clearly show signals at 1600 and $1497 \mathrm{~cm}^{-1}$ as well as at 758 and $699 \mathrm{~cm}^{-1}$ corresponding respectively to the signals from chemical bonds: $\mathrm{C}=\mathrm{C}$ (stretching vibrations of benzene-rings) and the out-of-plane bending of $\mathrm{C}-\mathrm{H}$ of monosubstituted benzene-ring). Moreover, the absence of signals from $\mathrm{O}-\mathrm{H}$ bond vibrations is notable. Signals in the region of $3000 \mathrm{~cm}^{-1}$ can be attributed to $\mathrm{C}-\mathrm{H}$ bond dranes in both the alkyl chain and the aromatic ring. The significant similarity of both spectra should be emphasized, which represent mainly the same nanofiber material-polystyrene, which comprises the outer layer of the PS/Alg nanomaterial. Nevertheless, the infrared spectra proved the stability of the PS nanofibers during the preparation of composite material and indicated that the surface properties of PS/Alg material are dominated by PS nanofibers properties.

Successively, the contact angles (CA) measured for electrospun fibers with the immobilized bacteria were analyzed and they are presented in Figure 5. Additionally, calculated values are collected in Table 1. Hydrophobicity of obtained material was characterized based on a measurement of contact angle (DSA100E Drop Shape Analyzer, KRÜSS GmbH, Hamburg, Germany). In general, materials with liquid drop CA on their surface greater than $90^{\circ}$ are hydrophobic, and with CA lower than $90^{\circ}$ are hydrophilic. PS/Alg nanofibers showed slightly hydrophobic $\left(\mathrm{CA}>90^{\circ}\right)$ properties when a drop of water was applied. This is directly connected to polystyrene hydrophobic properties and was not affected by the presence of sodium alginate hydrogels. Moreover, the presence of alginate decreases the CA in the material, as we can observe higher values of CA for PS than for PS/Alg. 


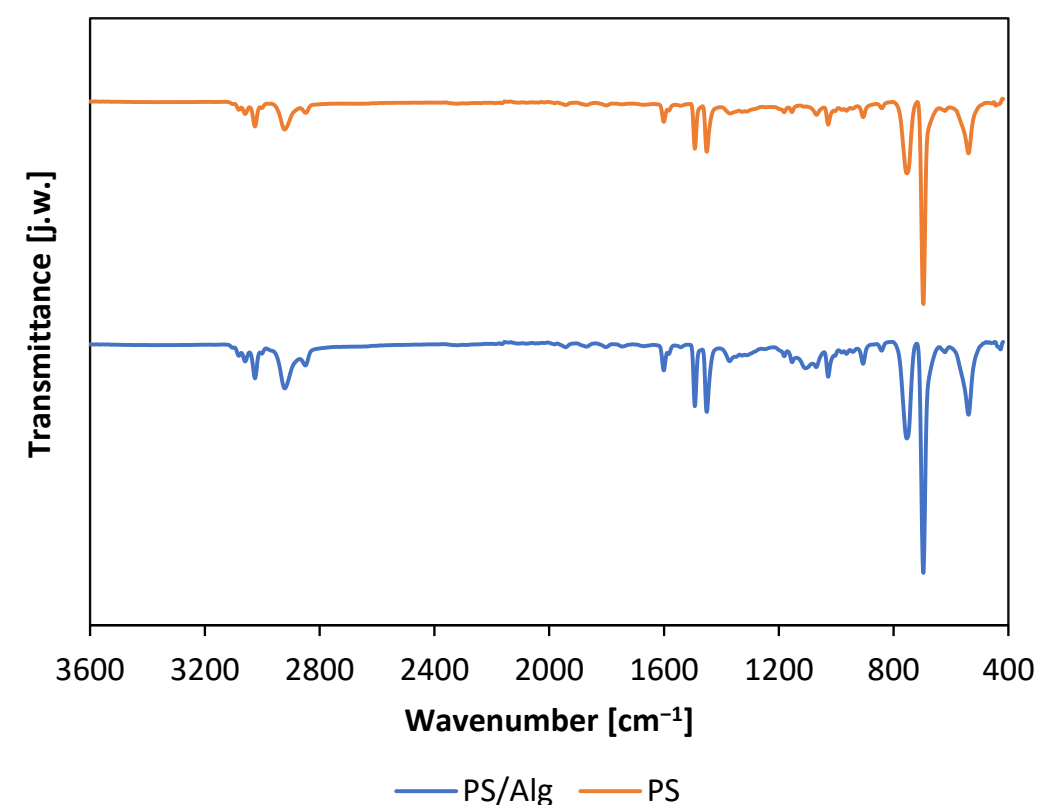

Figure 4. Infrared spectra of polystyrene nanofibers (PS) and polystyrene nanofibers with alginate hydrogel immobilized bacteria (PS/Alg).

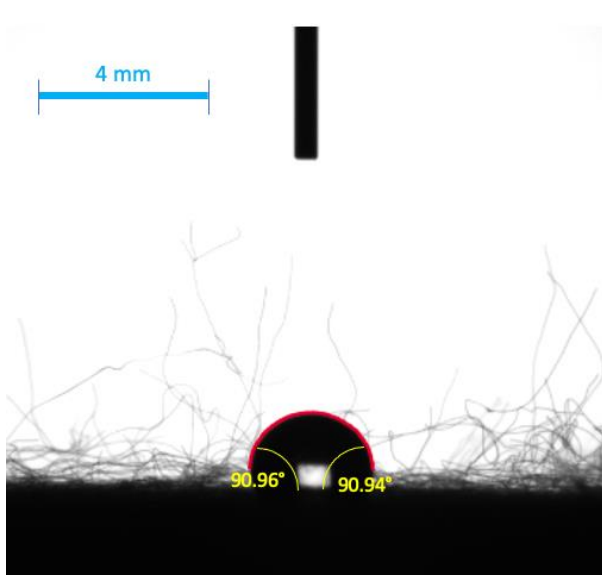

(a)

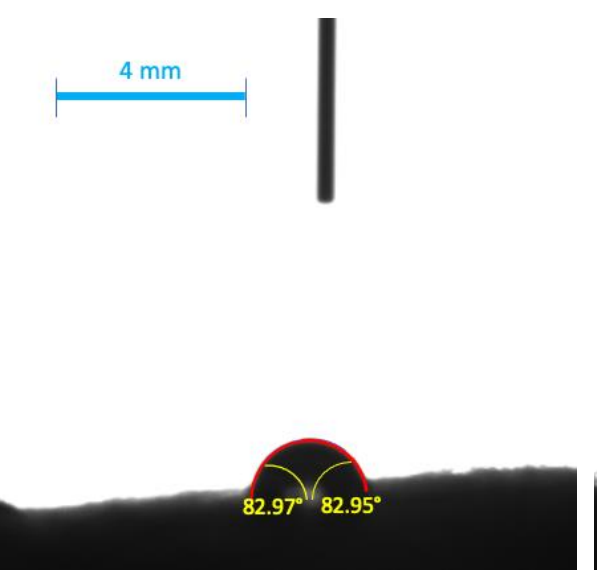

(b)

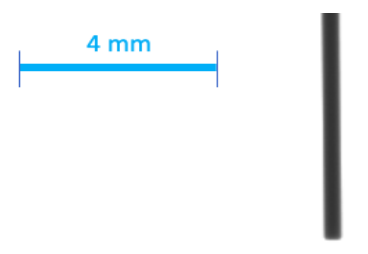

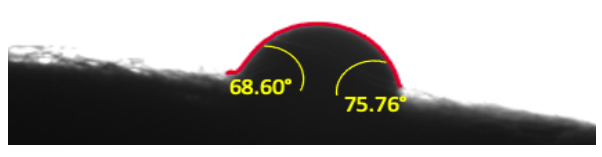

(c)

Figure 5. Contact angles of electrospun nanofibers from polystyrene-alginate-L. plantarum 2675 obtained with: (a) water; (b) MRS broth; (c) milk (2\% fat).

Table 1. Contact angles values of tested materials with selected dietary liquids.

\begin{tabular}{|c|c|c|c|c|}
\hline Material & Medium & Left Angle $\left[{ }^{\circ}\right]$ & Right Angle $\left[{ }^{\circ}\right]$ & Average Angle $\left[{ }^{\circ}\right]$ \\
\hline \multirow{3}{*}{ PS } & Water & $97.10 \pm 3.6$ & $97.10 \pm 3.6$ & $97.10 \pm 3.6$ \\
\hline & Broth & $97.23 \pm 1.0$ & $97.23 \pm 1.0$ & $97.23 \pm 1.0$ \\
\hline & Milk (2\% fat) & $77.24 \pm 2.2$ & $77.24 \pm 2.2$ & $77.24 \pm 2.2$ \\
\hline \multirow{3}{*}{ PS/Alg } & Water & $91.0 \pm 2.9$ & $90.9 \pm 3.3$ & $91.0 \pm 3.1$ \\
\hline & Broth & $83.0 \pm 3.3$ & $83.0 \pm 4.1$ & $83.0 \pm 3.7$ \\
\hline & Milk (2\% fat) & $68.7 \pm 0.3$ & $75.8 \pm 5.5$ & $72.2 \pm 2.9$ \\
\hline
\end{tabular}

These result correspond to results presented by Huan et al. who obtained water CA $106 \pm 1.5^{\circ}$ and $90 \pm 1.2^{\circ}$ when electrospinning PS nanofibers from DMF and THF respectively (Huan et al., 2015 [29]). The lower contact angle was obtained for broth and milk and equals $83.0 \pm 3.7^{\circ}$ and $72.2 \pm 2.89^{\circ}$, respectively, which means that both liquids 
possess the higher wetting ability. This could be caused by the presence of additives like proteins, sugars, and lipids, of which some are surface-active agents responsible for increasing wetting ability (Lorentz, Rogers and Jones, 2007 [30]; Campos Bernardes et al., 2012 [31]). A similar conclusion was drawn by Handojo et al. who reported that CA for water was higher than for whole milk on a glass surface and was equal to $49.5 \pm 3.1^{\circ}$ and $21.0 \pm 4.7^{\circ}$, respectively (Handojo et al., 2009 [32]).

\subsection{Bacterial Metabolic Activity}

Probiotic bacteria cells' survivability is challenged by heat processing methods, compromising their functionality. To enhance the thermal stability of cells, various immobilization techniques are applied. For this purpose, the analysis of the metabolic activity of bacteria immobilized into the produced polystyrene electrospun nanofibers/alginate hydrogel was performed. The metabolic activity of the cells was measured based on the MTT and alamarBlue assays, comparing the obtained results with traditionally preserved probiotics (lyophilized and encapsulated in sodium alginate). The results collected in Figure 6a present a decrease of cells' metabolic activity upon $24 \mathrm{~h}$ exposition to elevated temperature and UV radiation, regardless of preservation technique. However, the electrospun-fibers immobilized cells possessing the highest metabolic activity of the analyzed samples. The type of the factor influencing cells was also meaningless, which proves good protective properties of the produced fibers.

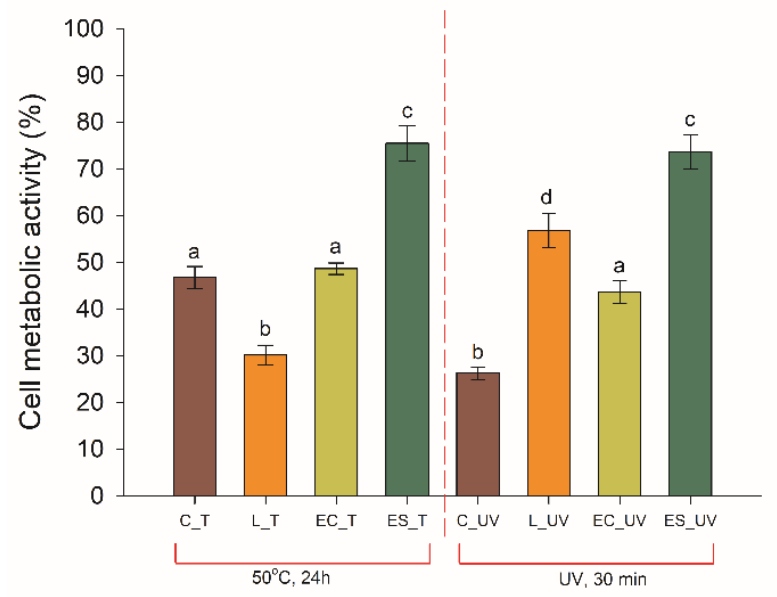

(a)

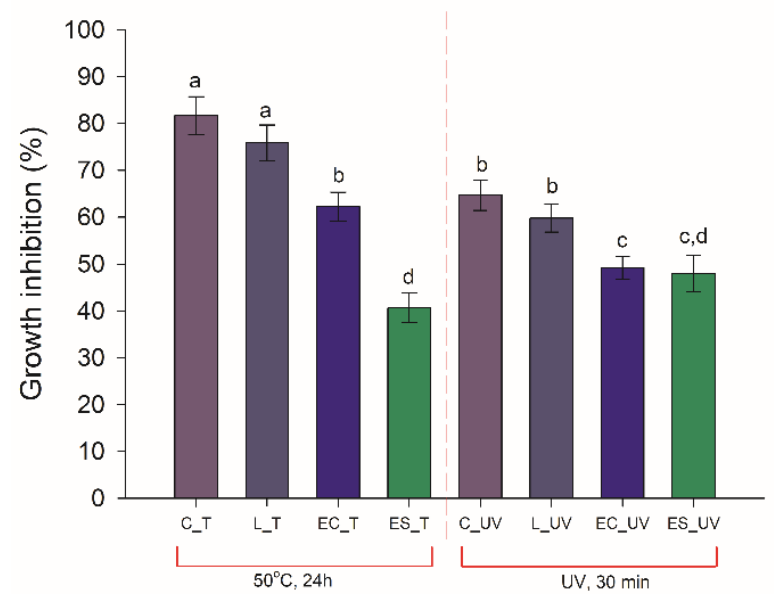

(b)

Figure 6. Results of the measurements of: (a) cells' metabolic activity, (b) growth inhibition of the cells, performed for control (C), lyophilized (L), alginate hydrogel-encapsulated (EC), and electrospun fibers immobilized (ES) cells of $L$. plantarum 2675 exposed to increased temperature $\left(50{ }^{\circ} \mathrm{C}, 24 \mathrm{~h}\right)$ or UV radiation $(\lambda=253 \mathrm{~nm}, 30 \mathrm{~min})$. Error bars represent the standard error of the mean of the three replicates in three independent experiments. Different lowercase letters suggest the significant differences among mean values for each treatment group $(t$-test; $p<0.05)$.

Moreover, these results are also in consistency with the alamarBlue test results which measures cellular respiration during proliferation. In this case, the electrospun fibers immobilized bacteria were characterized with low growth inhibition, equal to $40 \%$ and $48 \%$ by the applied temperature and UV light, respectively (Figure $6 \mathrm{~b}$ ). At the same time, the growth of free cells was inhibited by $81 \%$ (exposure to higher temperature) and $64 \%$ (exposure to UV radiation), and a significant decline in growth was observed for other analyzed samples. The protective effect of the matrix surrounding the cells on bacterial proliferation properties was especially visible when the UV light was applied. The free and lyophilized cells showed over a $60 \%$ decline in growth, while for immobilized cells it was around $10 \%$ lower.

The protection efficiency of L. plantarum 2675 cells by the produced membrane was investigated proving increased cell metabolic activity and growth under heat and UV 
radiation treatment in bath, MTT, and alamarBlue tests. Better thermal stability of the Lactobacillus cells encapsulated in the core-shell fiber mat (PVA) was noted by Feng et al. (2020) [33], with the viability loss of $0.32 \log \left(\mathrm{CFU} \mathrm{mL}{ }^{-1}\right)$ after $30 \mathrm{~min}$ in $70^{\circ} \mathrm{C}$. As suggested earlier by Feng et al. (2018) [34], the high capacity of the produced PS nanofibers might be related to the shielding effect of the nanomaterial, thus physically inhibiting the hot diffusion into the material. The combination of polymer and hydrogel was successfully applied by Gensheimer et al. (2011) [35]. They immobilized the E. coli and M. luteus cells in PVA-hydrogel and obtained microparticles that were linked with PLA, PVB, or PCL nanofibers. However, the authors tested only protection against organic solvents. Hence it is hard to compare their results with ours. Moreover, it should be underlined, that the review prepared by Stojanov and Barlec (2020) [36] includes the most frequently used polymers used in nanofibers production for cell immobilization and does not mention broader data about polystyrene. Our study can be considered as a valuable contribution to the present state of knowledge as a proof of usability of the PS nanofibers with alginate hydrogel to immobilize bacteria. The method can be applied mainly for Gram-positive bacteria with cell structure similar to Lactobacillus cells. For other groups of bacteria, Gramnegative, the effectiveness of the hybrid material should be similar. However, because of the differences between cell walls of Gram-positive and Gram-negative bacteria, for the second group additional experiments must be conducted.

\section{Conclusions}

Increasing demand for safe, efficient, and environmentally-safe solutions for pharmaceutical and food industries force researchers to look for new methods of bacteria storage. We propose that composite polystyrene materials/alginate immobilized bacteria meets mentioned expectations, since the research has proved the stability of the hybrid material. Significant reduction of the toxic effect of UV radiation and the higher temperature $\left(50^{\circ} \mathrm{C}\right.$, $24 \mathrm{~h}$ ) was observed when the bacteria were immobilized in composite in comparison with free cells and cells in alginate only. Good wettability properties make the hybrid material a promising tool for industrial applications.

Author Contributions: Conceptualization, A.Z., W.S., and A.G.; methodology, A.Z., K.J., and A.G.; validation, A.B. and J.Z.; formal analysis, A.B., E.K. and T.J.; investigation, A.Z., K.J. and A.G.; resources, A.Z. and A.G.; data curation, K.J.; writing-original draft preparation, A.Z. and A.G.; writing-review and editing, A.Z. and W.S.; visualization, A.Z. and J.Z.; supervision, E.K. and T.J.; project administration, W.S.; funding acquisition, W.S. All authors have read and agreed to the published version of the manuscript.

Funding: The research was funded by Polish Ministry of Science and Higher Education (Grant No. 0912/SBAD/2015)—a subvention for Poznan University of Technology.

Institutional Review Board Statement: Not applicable.

Informed Consent Statement: Not applicable.

Data Availability Statement: No new data were created or analyzed in this study. Data sharing is not applicable to this article.

Conflicts of Interest: The authors declare no conflict of interest.

\section{References}

1. Thomas, E. Microbial growth and physiology: A call for better craftsmanship. Front. Microbiol. 2015, 6, 1-12.

2. Smułek, W.; Zdarta, A.; Grzywaczyk, A.; Guzik, U.; Siwińska-Ciesielczyk, K.; Ciesielczyk, F.; Strzemiecka, B.; Jesionowski, T.; Voelkel, A.; Kaczorek, E. Evaluation of the physico-chemical properties of hydrocarbons-exposed bacterial biomass. Colloid Surf. B 2020, 196, 111310. [CrossRef] [PubMed]

3. Rahman, F.U.; Andree, K.B.; Salas-Massó, N.; Fernandez-Tejedor, M.; Sanjuan, A.; Figueras, M.J.; Furones, M.D. Improved culture enrichment broth for isolation of Arcobacter-like species from the marine environment. Sci. Rep. 2020, 10, 14547. [CrossRef] [PubMed] 
4. Cultrera, R.; Torelli, R.; Sarnicola, C.; Segala, D.; Mengoli, A.; Chiaretto, G.; Perri, P.; Sanguinetti, M. Identification and molecular characterization of Subramaniula asteroides causing human fungal keratitis: A case report. BMC Infect. Dis. 2021, 21, 4-9. [CrossRef] [PubMed]

5. Schön, T.; Werngren, J.; Machado, D.; Borroni, E.; Wijkander, M.; Lina, G.; Mouton, J.; Matuschek, E.; Kahlmeter, G.; Giske, C.; et al. Antimicrobial susceptibility testing of Mycobacterium tuberculosis complex isolates-The EUCAST broth microdilution reference method for MIC determination. Clin. Microbiol. Inf. 2020, 26, 1488-1492. [CrossRef]

6. Xie, L.; Chen, Z.; Liu, W.; Gu, D.; Yu, Y.; Chen, X.; Wu, Y.; Xu, N.; Xie, J.; Zhao, G.; et al. A sensitive EZMTT method provides microscale, quantitative and high-throughput evaluation of drug efficacy in the treatment of Mycobacterium tuberculosis infectious diseases. J. Microbiol. Methods 2021, 181, 106136. [CrossRef]

7. Mikolajczyk, A.; Stefaniuk, E.; Bosacka, K.; Hryniewicz, W. Właściwości i zastosowanie podłoży bakteriologicznych. [Properties and uses of bacteriological media. Postępy Mikrobiol. 2016, 55, 320-329.

8. Drauz, K.; Waldmann, H. Immobilization of Enzymes. In Enzyme Catalysis in Organic Synthesis, 1st ed.; Drauz, K., Gröger, H., May, O., Eds.; Wiley-VCH Verlag: Weinheim, Germany, 1995; pp. 73-87.

9. Zhu, Y. Immobilized Cell Fermentation for Production of Chemicals and Fuels. In Bioprocessing for Value-Added Products from Renewable Resources, 1st ed.; Yang, S.-T., Ed.; Elsevier Science: New York, NY, USA, 2007; pp. 373-396.

10. Willaert, R.G.; Baron, G.V. Gel entrapment and micro-encapsulation: Methods, applications and engineering principles. Rev. Chem. Eng. 1996, 12, 160-205. [CrossRef]

11. Tripathi, M.K.; Giri, S.K. Probiotic functional foods: Survival of probiotics during processing and storage. J. Funct. Food 2014, 9 , 225-241. [CrossRef]

12. Rocha, C.E.; Silva, M.F.; Guedes, A.C.; Carvalho, T.P.; Eckstein, C.; Ribeiro, N.Q.; Santos, D.A.; Melo, M.M.; Araújo, M.S.; MartinsFilho, O.A.; et al. Alginate-chitosan microcapsules improve vaccine potential of gamma-irradiated Listeria monocytogenes against listeriosis in murine model. Int. J. Biol. Macromol. 2021, 176, 567-577. [CrossRef]

13. Penhasi, A.; Reuveni, A.; Baluashvili, I. Microencapsulation May Preserve the Viability of Probiotic Bacteria during a Baking Process and Digestion: A Case Study with Bifidobacterium animalis Subsp. lactis in Bread. Curr. Microbiol. 2021, 78, 576-589. [CrossRef]

14. Cook, M.; Tzortzis, G.; Charalampopoulos, D.; Khutoryanskiy, V. Microencapsulation of probiotics for gastrointestinal delivery. J. Control Release 2012, 162, 56-67. [CrossRef]

15. Ghoname, R.M.; El-Sayed, H.S.; Ghozlan, H.A.; Sabry, S.A. Application of probiotic bacteria for the improvement of sea bream (Sparus aurata) larval production. Egypt. J. Aquat. Biol. Fish. 2020, 24, 371-398. [CrossRef]

16. Stanishevsky, A.V.; Wetuski, J.D.; Yockell-Lelièvre, H. Crystallization and stability of electrospun ribbon- and cylinder-shaped tungsten oxide nanofibers. Ceram. Int. 2016, 42, 388-395. [CrossRef]

17. Li, L.; Peng, S.; Lee JK, Y.; Ji, D.; Srinivasan, M.; Ramakrishna, S. Electrospun hollow nanofibers for advanced secondary batteries. Nano Energy 2017, 39, 111-139. [CrossRef]

18. Ali, M.; Ain, Q.T.; Huan, H.J. Branched nanofibers for biodegradable facemasks by double bubble electrospinning. Acta Chem. Malays. 2020, 4, 40-44. [CrossRef]

19. Ma, P.X.; Zhang, R. Synthetic nanoscale fibrous matrix. J. Biomed. Mat. Res. A 1999, 46, 60-72. [CrossRef]

20. Xu, D.; Samways, D.S.K.; Dong, H. Fabrication of self-assembling nanofibers with optimal cell uptake and therapeutic delivery efficacy. Bioact. Mater. 2017, 2, 260-268. [CrossRef] [PubMed]

21. Wang, Y.; Zheng, M.; Lu, H.; Feng, S.; Ji, G.; Cao, J. Template synthesis of carbon nanofibers containing linear mesocage arrays. Nanoscale Res. Lett. 2010, 5, 913-916. [CrossRef] [PubMed]

22. Huang, Z.-M.; Zhang, Y.; Kotaki, M.; Ramakrishna, S. A review on polymer nanofibers by electrospinning and their applications in nanocomposites. Compos. Sci. Technol. 2003, 63, 2223-2253. [CrossRef]

23. Bhardwaj, N.; Kundu, S.C. Electrospinning: A fascinating fiber fabrication technique. Biotechnol. Adv. 2010, $28,325-347$. [CrossRef] [PubMed]

24. Bao, J.; Li, H.; Xu, Y.; Chen, S.; Wang, Z.; Jiang, C.; Li, H.; Wei, Z.; Sun, S.; Zhao, W.; et al. Multi-functional polyethersulfone nanofibrous membranes with ultra-high adsorption capacity and ultra-fast removal rates for dyes and bacteria. J. Mater. Sci. Technol. 2021, 78, 131-143. [CrossRef]

25. Jayani, T.; Sanjeev, B.; Marimuthu, S.; Uthandi, S. Bacterial Cellulose Nano Fiber (BCNF) as carrier support for the immobilization of probiotic, Lactobacillus acidophilus 016. Carbohydr. Polym. 2020, 250, 116965. [CrossRef] [PubMed]

26. Mamvura, C.I.; Moolman, F.S.; Kalombo, L.; Hall, A.N.; Thantsha, M.S. Characterisation of the Poly-(Vinylpyrrolidone)-Poly(Vinylacetate-Co-Crotonic Acid) (PVP:PVAc-CA) Interpolymer Complex Matrix Microparticles Encapsulating a Bifidobacterium lactis Bb12 Probiotic Strain. Probiot. Antimicrob. Proteins 2011, 3, 97-102. [CrossRef]

27. Yu, H.; Liu, W.; Li, D.; Liu, C.; Feng, Z.; Jiang, B. Targeting Delivery System for Lactobacillus Plantarum Based on Functionalized Electrospun Nanofibers. Polymers 2020, 12, 1565. [CrossRef]

28. Deng, G.; Deng, X.; Deng, J.; Lu, X.; Kang, X.; Song, Y. Performance Evaluation of an Electrospun Nanofiber Mat as Samplers for the Trap of Trace Heavy Metals in Atmospheric Particles and Its Application. Anal. Sci. 2020, 36, 1453-1459. [CrossRef] [PubMed]

29. Huan, S.; Liu, G.; Han, G.; Cheng, W.; Fu, Z.; Wu, Q.; Wang, Q. Effect of experimental parameters on morphological, mechanical and hydrophobic properties of electrospun polystyrene fibers. Materials 2015, 8, 2718-2734. [CrossRef]

30. Lorentz, H.; Rogers, R.; Jones, L. The impact of lipid on contact angle wettability. Optom. Vis. Sci. 2007, 84, 946-953. [CrossRef] 
31. Bernardes, P.C.; Araújo, E.A.; Pires, A.C.; Júnior, J.F.Q.F.; Lelis, C.; De Andrade, N.J. Work of adhesion of dairy products on stainless steel surface. Braz. J. Microbiol. 2012, 43, 1261-1268. [CrossRef]

32. Handojo, A.; Zhai, Y.; Frankel, G.; Pascall, M.A. Measurement of adhesion strengths between various milk products on glass surfaces using contact angle measurement and atomic force microscopy. J. Food Eng. 2009, 92, 305-311. [CrossRef]

33. Feng, K.; Huang, R.-M.; Wu, R.-Q.; Wei, Y.-S.; Zong, M.-H.; Linhardt, R.J.; Wu, H. A novel route for double-layered encapsulation of probiotics with improved viability under adverse conditions. Food Chem. 2020, 310, 125977. [CrossRef] [PubMed]

34. Feng, K.; Zhai, M.Y.; Zhang, Y.; Linhardt, R.J.; Zong, M.H.; Li, L.; Wu, H. Improved Viability and Thermal Stability of the Probiotics Encapsulated in a Novel Electrospun Fiber Mat. J. Agric. Food Chem. 2018, 66, 10890-10897. [CrossRef] [PubMed]

35. Gensheimer, M.; Brandis-Heep, A.; Agarwal, S.; Thauer, R.K.; Greiner, A. Polymer/Bacteria Composite Nanofiber Nonwovens by Electrospinning of Living Bacteria Protected by Hydrogel Microparticles. Macromol. Biosci. 2019, 11, 333-337. [CrossRef] [PubMed]

36. Stojanov, S.; Berlec, A. Electrospun Nanofibers as Carriers of Microorganisms, Stem Cells, Proteins, and Nucleic Acids in Therapeutic and Other Applications. Front. Bioeng. Biotechnol. 2020, 8, 130. [CrossRef] [PubMed] 